\title{
STUDY OF WEIGHT VARIATION DURING ANTI-TUBERCULOSIS TREATMENT IN TUBERCULOSIS PATIENTS PUT ON DOTS IN RNTCP IN CENTRAL INDIA
}

\author{
Ratan Kumar', Rajesh Kumar Ahirwar ${ }^{2}$, Lokendra Dave ${ }^{3}$, Nishant Srivastava ${ }^{4}$, Pritesh Goutam 5 , A. K. Shrivastava 6 \\ ${ }^{1}$ Associate Professor, Department of Pulmonary Medicine, L. N. Medical College, Bhopal, Madhya Pradesh. \\ ${ }^{2}$ Assistant Professor, Department of Community Medicine, L. N. Medical College, Bhopal, Madhya Pradesh. \\ ${ }^{3}$ Professor and HOD, Department of TB and Chest, Gandhi Medical College, Bhopal. \\ ${ }^{4}$ Associate Professor, Department of TB and Chest, Gandhi Medical College, Bhopal. \\ ${ }^{5}$ Assistant Professor, Department of Psychiatry, L. N. Medical College, Bhopal, Madhya Pradesh. \\ ${ }^{6}$ Associate Professor, Department of Pulmonary Medicine, L. N. Medical College, Bhopal, Madhya Pradesh.
}

\section{ABSTRACT}

\section{BACKGROUND}

Tuberculosis remains a global public health problem and major cause of death from a single infectious agent among adults in India and other developing countries.

The aim of this study is to observe weight variation during anti-tuberculosis treatment in patients put on DOTS in RNTCP.

\section{MATERIALS AND METHODS}

This is a retrospective study of diagnosed TB patients from all age groups, attending OPD of various departments at LN Medical College and JK Hospital, Bhopal, MP (India) from January 2012 to October 2015.

\section{RESULTS}

Out of total 375 patients, distribution of patients were as follows, 53.87\% (202/375) males, 46.13\% (173/375) females, 83.20\% (312/375) category I and 16.80\% (63/375) category II, 91.46\% (343/375) gained weight, 4.27\% (16/375) weight remained constant and $4.27 \%(16 / 375)$ lose weight. Age group wise maximum percentage of patients who gained weight was $96.30 \%$ in age group of 0 - 14 years, whereas maximum percentage of patients suffering weight loss was 5.00\% in age group above 45 years.

\section{CONCLUSION}

Treatment success rate found higher $91.46 \%$ (343/375) in those patients who gained weight. In the present study, higher weight gain (96.30\%), higher successful treatment (98.18\%), lower default rate $(1.81 \%)$ and lower weight loss $(1.85 \%)$ observed in age group of 0 - 14 years, whereas lower weight gain (93.3\%), lower successful treatment (65.21\%), higher default rate (14.13\%), higher death rate $(13.04 \%)$ and higher weight loss (5.00\%) in age above 45 years.

\section{KEYWORDS}

Weight Variation, Anti-Tuberculosis Treatment, RNTCP, DOTS.

HOW TO CITE THIS ARTICLE: Kumar R, Ahirwar RK, Dave L, et al. Study of weight variation during anti-tuberculosis treatment in tuberculosis patients put on dots in RNTCP in Central India. J. Evolution Med. Dent. Sci. 2017;6(6):478-481, DOI: $10.14260 /$ Jemds/2017/104

\section{BACKGROUND}

Tuberculosis (TB) remains a major global public health problem and major cause of death from a single infectious agent among adults in India and developing countries.[1,2,3] The problem is further compounded by the emergence of HIV, Diabetes and DRTB. According to WHO 6.1 million TB cases reported in 2013, out of which 5.7 million cases were newly diagnosed and another 0.4 million were already on treatment.[4] The cases of TB are highest in Asia and Africa. India and China together account for approximately $40 \%$ of the world's TB cases.[2] The burden of TB in India is the highest accounting for one-fifth (21\%) of the global

Financial or Other, Competing Interest: None.

Submission 13-12-2016, Peer Review 03-01-2017,

Acceptance 12-01-2017, Published 19-01-2017.

Corresponding Author:

Dr. Ratan Kumar

Associate Professor

Department of Pulmonary Medicine,

L. N. Medical College, Bhopal,

Madhya Pradesh.

E-mail: ratan_vaish@yahoo.co.in

DOI: $10.14260 /$ jemds $/ 2017 / 104$

\section{(c) $(1)$}

incidence.[5] Every year 1.8 million new cases occur in India of which 0.8 million are infectious.[6] As per Revised National Tuberculosis Control Programme (RNTCP) 2011 in Madhya Pradesh, there were 90,764 cases registered for TB.[7] Tuberculosis is the archetypal wasting disease. The association of TB and nutritional status of patients has long been evident as older terms were used for TB such as the Greek term "phthisis" or "to waste away." [8] One study reported that moderate and severe malnutrition was a risk factor associated with early death during TB treatment in rural areas of Malawi.[9] Some studies have reported that weight loss should be considered as clinically relevant.[10,11,6,12,13] Some studies have suggested an association between meagre weight gain during TB therapy add risk of poor treatment outcome. ${ }^{[10,6,12]}$

In India, National Tuberculosis Control Programme (NTP) was launched in 1962. NTP was integrated and implemented through the General Public Health Services.[14] NTP could not achieve the objective because of low priority, managerial weakness, over dependence on x-ray chest for diagnosis and inadequate funding. In order to overcome the short comings in the NTP, the programme was revised jointly by WHO and Government of India in 1992. 
WHO declared TB, a global health emergency in April 1993.[6] The Revised National Tuberculosis Programme (RNTCP) has been implemented in 1993, guided by WHO and supported by world bank.[15] A five points strategy known as Directly Observed Treatment Short Course (DOTS) was launched in India in a phased manner under RNTCP in 1997 with objective of cure rate not less than $85 \%$ of infectious TB cases and at least $70 \%$ detection of new cases through quality sputum microscopy. ${ }^{[2,3]}$ With this background, we conducted this retrospective study.

\section{MATERIALS AND METHODS}

Present study was retrospectively conducted at LN Medical College and JK Hospital, Bhopal, a tertiary care centre among patients who were registered for treatment of category I and II under DOTS in RNTCP from nearby urban, rural areas and some other districts, between January 2012 and October 2015.

The data had been obtained from DOTS treatment cards, RNTCP referral register, patient record sheet of hospital, lab register and then used for analysis. Body weight of all patients included in this study was recorded in kilogram $(\mathrm{kg})$ at different interval including at time of starting of ATT and at end of treatment. Other variables of interest included in the analysis were sex, age, category (I and II) of patients, types of TB (sputum positive PTB, sputum negative PTB and EPTB) and treatment outcome, etc.

\section{Inclusion Criteria}

All patients registered as a case of category I and II tuberculosis.

\section{Exclusion Criteria}

Patients having comorbid disease like HIV and DRTB.

The patients had been treated with standard regimens of ATT drugs as provided by Government of India through RNTCP until completion of full course for both categories of patients. During initial intensive phase, all doses of weekly drug pack were administered in front of DOTS provider or health worker thrice weekly followed by continuation phase during this phase first dose of weekly drug pack administered in front of DOTS provider or health worker and rest two doses of weekly drug pack given to patients to be taken at their home as per protocol of RNTCP.

Data were scrutinised and cross checked twice in order to ensure accuracy, then corrected for any missing information.

\section{RESULTS}

Among total 453 patients, 375 patients were found eligible for the present study, whose body weight records were available at the time of initiation of treatment and at the end of treatment.

\begin{tabular}{|c|c|c|c|c|}
\hline & $\begin{array}{c}\text { Weight } \\
\text { Gain } \\
\% \text { (No.) } \\
{[91.46 \%} \\
(343)]\end{array}$ & $\begin{array}{c}\text { Weight } \\
\text { Constant } \\
\% \text { (No.) } \\
{[4.27 \%} \\
(16)]\end{array}$ & $\begin{array}{c}\text { Weight } \\
\text { Loss } \\
\% \text { (No.) } \\
{[4.27 \%} \\
(16)] \\
\end{array}$ & $\begin{array}{l}\text { Total } \\
{[375]}\end{array}$ \\
\hline CAT - I & $\begin{array}{c}92.62 \% \\
(289)\end{array}$ & $\begin{array}{c}3.85 \% \\
(12)\end{array}$ & $\begin{array}{c}3.53 \% \\
(11)\end{array}$ & $\begin{array}{c}83.20 \% \\
(312)\end{array}$ \\
\hline CAT - II & $\begin{array}{c}85.71 \% \\
(54)\end{array}$ & $\begin{array}{c}6.35 \% \\
(4)\end{array}$ & $\begin{array}{c}7.94 \% \\
(5)\end{array}$ & $\begin{array}{c}16.80 \% \\
(63)\end{array}$ \\
\hline Male & $\begin{array}{c}95.54 \% \\
(193)\end{array}$ & $\begin{array}{c}2.48 \% \\
\text { (5) }\end{array}$ & $\begin{array}{c}1.98 \% \\
(4)\end{array}$ & $\begin{array}{c}53.87 \% \\
(202)\end{array}$ \\
\hline
\end{tabular}

\begin{tabular}{|c|c|c|c|c|}
\hline Female & $\begin{array}{c}86.70 \% \\
(150)\end{array}$ & $\begin{array}{c}6.36 \% \\
(11)\end{array}$ & $\begin{array}{c}6.94 \% \\
(12)\end{array}$ & $\begin{array}{c}46.13 \% \\
(173)\end{array}$ \\
\hline Cured & $\begin{array}{c}92.90 \% \\
(131 / 141)\end{array}$ & $\begin{array}{c}3.55 \% \\
(5 / 141)\end{array}$ & $\begin{array}{c}3.55 \% \\
(5 / 141)\end{array}$ & $\begin{array}{c}37.60 \% \\
(141)\end{array}$ \\
\hline $\begin{array}{l}\text { Treatment } \\
\text { completed }\end{array}$ & $\begin{array}{c}90.60 \% \\
(212 / 234)\end{array}$ & $\begin{array}{c}4.70 \% \\
(11 / 234)\end{array}$ & $\begin{array}{c}4.70 \% \\
(11 / 234)\end{array}$ & $\begin{array}{c}62.40 \% \\
(234)\end{array}$ \\
\hline
\end{tabular}

Table 1. Weight Variation in Different Group of TB Patients

Out of total 375 patients, distribution of patients were as follows, $53.87 \% \quad(202 / 375)$ males, $46.13 \% \quad(173 / 375)$ females, $83.20 \%(312 / 375)$ category I and $16.80 \%(63 / 375)$ category II, $91.46 \%$ (343/375) gained weight, $4.27 \%$ $(16 / 375)$ weight remained constant and $4.27 \%$ (16/375) lose weight. Weight variation in the form of weight gain, weight constant and weight loss were observed as follows; $92.62 \%$ (289/312), 3.85\% (12/312) and $3.53 \% \quad(11 / 312)$ respectively in category I, 85.71\% (54/63), 6.35\% (4/63) and $7.94 \%$ (5/63) respectively in category II, 95.54\% (193/202), $2.48 \%(5 / 202)$ and $1.98 \%(4 / 202)$ in male patients, whereas $86.70 \%$ (150/173), 6.36\% (11/173) and 6.94\% (12/173) in female patients.

Among total 453 patients the overall treatment outcomes were as follows; $82.78 \%$ (375/453) treatment successful, $31.13 \%$ (141/453) cured, 51.66\% (234/453) completed treatment, 7.73\% (35/453) defaulted, 4.19\% (19/454) failed, $0.22 \%(1 / 453)$ relapse, $3.97 \%(18 / 453)$ died and $1.10 \%$ (5/453) transferred out.

\begin{tabular}{|c|c|c|c|c|}
\hline & $\begin{array}{c}\text { 0 - 14 } \\
\text { Years } \\
\%(\text { No.) } \\
{[14.40 \%} \\
(54)]\end{array}$ & $\begin{array}{c}15-45 \\
\text { Years } \\
\%(\text { No.) } \\
{[69.60 \%} \\
(261)]\end{array}$ & $\begin{array}{c}\text { Above } 45 \\
\text { Years } \\
\% \text { (No.) } \\
{[16.00 \%} \\
(60)]\end{array}$ & $\begin{array}{c}\text { Total } \\
\% \text { (No.) } \\
{[375]}\end{array}$ \\
\hline Cat - I & $\begin{array}{c}16.67 \% \\
(52)\end{array}$ & $\begin{array}{c}67.63 \% \\
(211)\end{array}$ & $\begin{array}{c}15.70 \% \\
(49)\end{array}$ & $\begin{array}{c}83.20 \% \\
(312)\end{array}$ \\
\hline Cat - II & $\begin{array}{c}3.17 \% \\
(2)\end{array}$ & $\begin{array}{c}79.35 \% \\
(50)\end{array}$ & $\begin{array}{c}17.48 \% \\
(11)\end{array}$ & $\begin{array}{c}16.80 \% \\
(63)\end{array}$ \\
\hline Male & $\begin{array}{c}15.84 \% \\
(32)\end{array}$ & $\begin{array}{c}63.86 \% \\
(129) \\
\end{array}$ & $\begin{array}{c}20.30 \% \\
(41)\end{array}$ & $\begin{array}{c}53.87 \% \\
(202) \\
\end{array}$ \\
\hline Female & $\begin{array}{c}12.71 \% \\
(22)\end{array}$ & $\begin{array}{c}76.31 \% \\
(132)\end{array}$ & $\begin{array}{c}10.98 \% \\
(19)\end{array}$ & $\begin{array}{c}46.13 \% \\
(173)\end{array}$ \\
\hline $\begin{array}{c}\text { Weight } \\
\text { Gain }\end{array}$ & $\begin{array}{c}96.30 \% \\
(52)\end{array}$ & $\begin{array}{c}90.04 \% \\
(235)\end{array}$ & $\begin{array}{c}93.33 \% \\
(56)\end{array}$ & $\begin{array}{c}91.46 \% \\
(343)\end{array}$ \\
\hline $\begin{array}{c}\text { Weight } \\
\text { Constant }\end{array}$ & $\begin{array}{l}1.85 \% \\
\text { (1) }\end{array}$ & $\begin{array}{c}5.36 \% \\
(14)\end{array}$ & $\begin{array}{c}1.67 \% \\
(1)\end{array}$ & $\begin{array}{c}4.27 \% \\
(16)\end{array}$ \\
\hline $\begin{array}{l}\text { Weight } \\
\text { Loss }\end{array}$ & $\begin{array}{c}1.85 \% \\
(1)\end{array}$ & $\begin{array}{c}4.60 \% \\
(12)\end{array}$ & $\begin{array}{l}5.00 \% \\
(3)\end{array}$ & $\begin{array}{c}4.27 \% \\
(16)\end{array}$ \\
\hline
\end{tabular}

Maximum number of patients $69.60 \%$ (261/375) were registered in age group of 15 - 45 years, whereas minimum number of patients $14.40 \%$ (54/375) were registered in age of 0 - 14 years. Maximum number of males and females patients were $63.86 \%(129 / 202)$ and $76.31 \%(132 / 173)$ registered in age group of 15 - 45 years. Age group wise maximum percentage of patients gained weight was $96.30 \%$ $(52 / 54)$ in age group of 0 - 14 years, whereas maximum percentage of patients suffered weight loss $5.00 \%(3 / 60)$ observed in age group above 45 years and maximum percentage of patients with constant weight $5.36 \%$ found in age group of 15 - 45 years. 


\begin{tabular}{|c|c|c|c|c|}
\hline & \multicolumn{4}{|c|}{ Weight Gain Range [\% (No.)] } \\
\hline & $\begin{array}{c}0-2 \mathrm{~kg} \\
{[20.99 \%} \\
(72)]\end{array}$ & $\begin{array}{c}3-4 \mathrm{~kg} \\
{[30.02 \%} \\
(103)]\end{array}$ & \begin{tabular}{|c|} 
Above \\
$4 \mathrm{~kg}$ \\
{$[48.99 \%$} \\
$(168)]$
\end{tabular} & $\begin{array}{l}\text { Total } \\
\text { [343] }\end{array}$ \\
\hline Male & $\begin{array}{c}18.13 \% \\
(35)\end{array}$ & $\begin{array}{c}29.02 \% \\
(56)\end{array}$ & $\begin{array}{c}52.85 \% \\
(102)\end{array}$ & $\begin{array}{c}56.27 \% \\
(193)\end{array}$ \\
\hline Female & $\begin{array}{c}24.67 \% \\
(37)\end{array}$ & $\begin{array}{c}31.33 \% \\
(47)\end{array}$ & $\begin{array}{c}44.00 \% \\
(66)\end{array}$ & $\begin{array}{c}43.73 \% \\
(150)\end{array}$ \\
\hline Cat - I & $\begin{array}{c}22.49 \% \\
(65)\end{array}$ & $\begin{array}{c}28.03 \% \\
(81)\end{array}$ & $\begin{array}{c}49.48 \% \\
(143)\end{array}$ & $\begin{array}{c}84.26 \% \\
(289)\end{array}$ \\
\hline Cat - II & $\begin{array}{c}12.96 \% \\
(7)\end{array}$ & $\begin{array}{c}40.74 \% \\
(22)\end{array}$ & $\begin{array}{c}46.30 \% \\
(25)\end{array}$ & $\begin{array}{c}15.76 \% \\
(54)\end{array}$ \\
\hline Cured & $\begin{array}{c}16.03 \% \\
(21)\end{array}$ & $\begin{array}{c}22.90 \% \\
(30)\end{array}$ & $\begin{array}{c}61.07 \% \\
(80)\end{array}$ & $\begin{array}{c}38.19 \% \\
(131)\end{array}$ \\
\hline $\begin{array}{l}\text { Treatment } \\
\text { Completed }\end{array}$ & $\begin{array}{c}24.06 \% \\
\text { (51) }\end{array}$ & $\begin{array}{c}34.43 \% \\
(73)\end{array}$ & $\begin{array}{c}41.51 \% \\
\text { (88) }\end{array}$ & $\begin{array}{c}61.81 \% \\
\text { (212) }\end{array}$ \\
\hline
\end{tabular}

Overall weight gain (in kilogram) range wise distribution of 343 patients were as follows: $20.99 \%$ (72/343), 30.02\% $(103 / 343)$ and $48.99 \%(168 / 343)$ in weight group of $0-2 \mathrm{~kg}$, 3 - $4 \mathrm{~kg}$ and above $4 \mathrm{~kg}$ respectively. Distribution of total 289 patients of category I who gained weight were as follows: $22.49 \%$ (65/289), 28.03\% (81/289) and 49.48\% (141/289) in gained weight group of $0-2 \mathrm{~kg}, 3-4 \mathrm{~kg}$ and above $4 \mathrm{~kg}$ respectively. Distribution of total 54 patients of category II who gained weight were as follows: $12.96 \%$ (7/54), 40.74\% $(22 / 54)$ and $46.30 \%(25 / 54)$ in gained weight groups of $0-2$ $\mathrm{kg}, 3-4 \mathrm{~kg}$ and above $4 \mathrm{~kg}$ respectively. Sex wise distribution of patients who gained weight in range of $0-2 \mathrm{~kg}, 3-4 \mathrm{~kg}$ and above $4 \mathrm{~kg}$ were $18.13 \%$ (35/193), 29.02\% (56/193) and $52.85 \%$ (102/193) respectively were males, whereas $24.67 \%$ $(37 / 150), \quad 31.33 \%(47 / 150)$ and $44.00 \% \quad(66 / 150)$ respectively were females.

Distribution of total 141 exclusive sputum smear positive patients were as follows; 58.16\% (86/141) males, $41.84 \%$ (59/141) females, $70.92 \%$ (100/141) category I and $29.08 \%$ (41/141) category II. Distribution of weight gain, weight constant and weight loss respectively were as follows; $96.00 \%(96 / 100), 2.00 \%(2 / 100)$ and $2.00 \%$ in category I, $85.36 \%$ (35/41), 7.32\% (3/41) and 7.32\% (3/41) category II, $95.12 \%$ (78/82), 2.44\% (2/82) and 2.44\% (2/82) in males, $89.83 \%$ (53/59), 5.08\% (3/59) and 5.08\% (3/59) in females.

In cured group $92.90 \%(131 / 141)$ patients gained weight, out of which $61.07 \%(80 / 131)$ gained weight above $4 \mathrm{~kg}$, whereas in treatment completed group $90.60 \%(212 / 234)$ patients gained weight, out of these only $41.51 \%$ (88/212) gained weight above $4 \mathrm{~kg}$.

Distribution of average weight gain were observed as follows: $4.39 \mathrm{~kg}$ (1505 kg/343 patients) in overall study patients, $4.34 \mathrm{~kg}$ (1533 kg/289 patients) in category I and $4.67 \mathrm{~kg}$ (252 kg/54 patients) in category II patients. Age group wise maximum average weight gain found in category I patients was $4.74 \mathrm{~kg}$ ( $218 \mathrm{~kg} / 46$ patients) in age group of above 45 years, whereas in category II $5.00 \mathrm{~kg}(10 \mathrm{~kg} / 2$ patients) found in age group of 0 - 14 years.

Overall weight variations in this study were ranged from weight loss of $8 \mathrm{~kg}$ to a weight gain of $16 \mathrm{~kg}$ in category I patients, whereas it ranged from weight loss of $6 \mathrm{~kg}$ to weight gain of $16 \mathrm{~kg}$ in category II.

\section{DISCUSSION}

Weight assessment might be an easily available low cost tool to predict outcome among patients receiving ATT in resource constrained setups.[16] Present study also showed association between weight variation during treatment and TB treatment outcome. Treatment success rate found higher $91.46 \%$ $(343 / 375)$ in those patients who gained weight, but very lower $4.27 \%$ (16/375) each in patients whose weight were either constant or reduced during treatment. Similar findings were observed in an Indian study.[12] Awal Khan et al reported that the patients who were either underweight at time of diagnosis or gained weight less than 5\% during initial two months of treatment were associated with an increased risk of relapse.[10]

Present study highlights the need of regular treatment and keeping body weight normal or required weight gain during treatment for better treatment outcome, which may be helpful to prevent the development of category II or DRTB. It is a suggestion that Government should also provide high calorie diet to patients along with ATT under DOTS in RNTCP.

In present study $92.62 \%(289 / 312)$ patients gained weight in category I, whereas $85.71 \%$ (54/63) in category II. Similar findings were also observed in an Indian study.[12] In this study, higher proportion of males (53.87\%) were observed as compared to females (46.13\%). Similar findings were reported from different part of India including studies at Aurangabad (62.4\%), Delhi (67.6\%), Nagpur (69.50\%) and South India.[12,8,3,17] In our study $46.13 \%$ (173/375) female patients were registered, while $30.49 \%, 32.40 \%$ and $37.60 \%$ female patients were registered respectively at Nagpur, Delhi and Aurangabad. $[8,3,17]$

In present study, higher weight gain (96.30\%), higher successful treatment $(98.18 \%)$, lower default rate $(1.81 \%)$ and lower weight loss (1.85\%) observed in age group of 0 14 years, whereas lower weight gain (93.3\%), lower successful treatment (65.21\%), higher default rate (14.13\%), higher death rate $(13.04 \%)$ and higher weight loss $(5.00 \%)$ in age above 45 years.

One study reported that average weight gain at the end of therapy was observed to be $3.2 \mathrm{~kg}$, in another study reported to be $3.3 \mathrm{~kg},{ }^{[12]}$ whereas in present study $4.39 \mathrm{~kg}$ observed.

Present study showed overall $3.97 \%$ patients died during the treatment period, which coincide with national average of $4.00 \%[18]$ and higher death rate $(13.04 \%)$ was observed in patients above 45 years of age, similar observation was seen in study done at Chennai.[12]

Dense population, little health awareness, incomplete treatment, increasing trend of nuclear family, lesser intake of normal balance diet, social stigma to attend DOTS centre and lesser pre-employment heath check-up of domestic/office helper are major risk factors for TB, which eventually affect individual family condition and economy of country as well.

Further studies with greater sample size are needed to corroborate our findings.

Present study has several limitations being it is a retrospective study and patients with unknown status of 
nutrition, education and other immunosuppressive comorbid diseases like diabetes, cancer, chemotherapy and CKD, etc.

\section{CONCLUSION}

Treatment success rate found higher $91.46 \%$ (343/375) in those patients who gained weight. Higher percentage of weight gain observed in male and category I patients in comparison to other group of patients, i.e. female and category II. Overall weight gain (in kilogram) range wise distribution of 343 patients were as follows: $20.99 \%, 30.02 \%$ and $48.99 \%$ in weight group of $0-2 \mathrm{~kg}, 3-4 \mathrm{~kg}$ and above 4 kg respectively.

Higher weight gain (96.30\%), higher successful treatment (98.18\%), lower default rate $(1.81 \%)$ and lower weight loss $(1.85 \%)$ observed in age group of 0 - 14 years, whereas lower weight gain (93.3\%), lower successful treatment (65.21\%), higher default rate (14.13\%), higher death rate $(13.04 \%)$ and higher weight loss $(5.00 \%)$ in age above 45 years. Patient's age group above 45 years need for more evaluation to rule out other risk factors including poor nutritional status, diabetes, obesity, cancer, HIV, renal disease, organ transplant, chemotherapy, cardiac disease, etc.

Being this is a retrospective study, it has few limitations as unable to get record related to diet habits, comorbidities, addiction and treatment history of steroids, etc. of registered patients.

\section{Acknowledgement}

The authors express deep gratitude to all RNTCP officials including Dr. Lokendra Dave (State Chairman, STF, RNTCP, MP), Dr. Atul Kharate (STO, MP), DTO, Bhopal and MO-RNTCP (J. K. Hospital) for the use of DOTS Centre data. Additionally, we would like to thank all the patients, DOTS provider and Microscopy Technician at DOTS Centre. We also recognise the peer reviewers whose suggestions greatly improved this manuscript as well as Dr. Shyam Krishna Vaish, Astha Agrahari, Divyansh, Vikrant and Kashish.

Permission received from - IEC \& RNTCP Department.

\section{List of Abbreviations}

TB: Tuberculosis.

RNTCP: Revised National Tuberculosis Control Programme.

DOTS: Directly Observed Treatment Short course chemotherapy.

EPTB: Extra-pulmonary tuberculosis.

PTB: Pulmonary tuberculosis.

HIV: Human Immunodeficiency Virus.

ATT: Anti-Tuberculosis Treatment.

CKD: Chronic Kidney Disease.

DM: Diabetes Mellitus.

\section{REFERENCES}

[1] Tuberculosis fact sheet $\mathrm{N}^{\circ} 104$. World Health Organization. November 2010. Retrieved 26 July 2011. www.who.int/mediacentre/factsheets/fs104/en/

[2] Stop TB. Geneva: World Health Organization. Partnership and World Health Organization. An international roadmap for tuberculosis research 2011.

[3] Directorate general of health services, ministry of health and family welfare nirman bhavan. New Delhi: 2010.

[4] Global tuberculosis control 2014, WHO, Geneva 2014.

[5] www.who.int/tb/publications/global_report/en/.

[6] District wise performance of RNTCP. TB India 2011:114-5. http://www.tbcindia.org

[7] Krapp F, Veliz JC, Cornejo E, et al. Bodyweight gain to predict treatment outcome in patients with pulmonary tuberculosis in Peru. Int $\mathrm{J}$ Tuberc Lung Dis 2008;12(10):1153-9.

[8] TB statistics for India-TB facts.org 2012. Available at: http://wwwtbfacts.org/tb-statics-india.html.

[9] Lettow VM, Fewzi WW, Semba RD. Triple trouble: the role of malnutrition in tuberculosis and human immunodeficiency virus co-infection. Nutr Rev 2003;61(3):81-90.

[10] Zachariah R, Spielmann MP, Harries AD, et al. Moderate to severe malnutrition in patients with tuberculosis is a risk factor associated with early death. Trans R Soc Trop Med Hyg 2002;96(3):291-4.

[11] Khan A, Sterling TR, Reves R, et al. Lack of weight gain and relapse risk in a large tuberculosis treatment trail. Am J Respir Crit Care Med 2006;174(3):344-8.

[12] Gillespie SH, Kennedy N. Weight as a surrogate marker of treatment response in tuberculosis. Int J Tuberc Lung Dis 1998;2(6):522-3.

[13] Vasantha M, Gopi PG, Subramani R. Weight gain in patients with tuberculosis treated under directly observed treatment short-course (DOTS). Indian J Tuberc 2009;56(1):5-9.

[14] Central TB division. Directorate general of health services, ministry of health and family welfare, Nirman Bhavan, New Dehli 110011, 2006. http://www.tbcindia.org

[15] Yew WW, Leung CC. Prognostic significance of early weight gain in underweight patients with tuberculosis. AM J Respir Crit Care Med 2006;174(3):236-7.

[16] Sarin R, Dey LBS. Indian national tuberculosis programme: revised strategy. Ind J Tub 1995;42:95100.

[17] Bernabe-Ortiz A, Carcamo CP, Sanchez JF, et al. Weight variation over time and its association with tuberculosis treatment outcome: a longitudinal analysis. PLoS one 2011;6(4):e18474.

[18] Central TB division, Ministry of health and family welfare, nirman bhawan. Mar, TB India 2009, RNTCP status report, New Delhi 2009:1-5. 